\title{
Glyphosate Tolerant Volunteer Corn Control at two DEVELOPMENT STAGES ${ }^{1}$
}

\author{
Controle do Milho Voluntário Tolerante ao Glyphosate em dois Estádios de Desenvolvimento
}

COSTA, N.V. ${ }^{2}$, ZOBIOLE, L.H.S. ${ }^{3}$, SCARIOT, C.A. ${ }^{2}$, PEREIRA, G.R. ${ }^{2}$, and MORATELLI, G. ${ }^{4}$

\begin{abstract}
The loss of grains during the harvest of glyphosate tolerant corn may generate volunteer plants, which can interfere in the conventional or glyphosate crop in succession. The current work aim to evaluate the control of the volunteer corn glyphosate tolerant under two weed stages. Aimed to evaluate the control of volunteer glyphosate tolerant corn in two stages of development. There were conducted two experiments with hybrid 2B688 HR (lepidoptera and glyphosate tolerant), the application were at $\mathrm{V}^{5}$ and $\mathrm{V}^{8}$ stage. The experiment was randomized block design with four replicates, using the treatments: haloxyfop at 25, 50 and $62 \mathrm{~g} \mathrm{ha}^{-1}$ alone and associated with 2,4-D at $670 \mathrm{~g} \mathrm{ha}^{-1}$ or fluroxypyr at $200 \mathrm{~g} \mathrm{ha}^{-1}$. The standard was clethodim at $84 \mathrm{~g} \mathrm{ha}^{-1}$ with 2,4-D and fluroxypyr at same rates. The applications of haloxyfop and clethodim both isolated or in a mixture with 2,4-D and fluroxypyr at $\mathrm{V}^{5}$ stage showed total control (100\%) at 32 and 39 days after the application, except for haloxyfop + 2,4-D $\left(25+670 \mathrm{~g} \mathrm{ha}^{-1}\right)$ mixture, which did not provided adequate control. At $\mathrm{V}^{8}$ stage, haloxyfop + 2,4-D $\left(50+670 \mathrm{~g} \mathrm{ha}^{-1}\right)$ and haloxyfop $+2,4-\mathrm{D}\left(62+670 \mathrm{~g} \mathrm{ha}^{-1}\right)$ mixtures took up to 6 and 10 days or longer to reach adequate to excellent control, when compared to haloxyfop isolated applications in the same doses, respectively. Either isolated clethodim or mixed with 2, 4-D and fluroxypyr did not show adequate control. The treatments showed efficient control on volunteer corn plants at $\mathrm{V}^{5}$ stage, except for haloxyfop + 2, 4-D (25 + $\left.670 \mathrm{~g} \mathrm{ha}^{-1}\right)$ mixture. At $\mathrm{V}^{8}$ stage applications, haloxyfop either isolated or mixture with fluroxypyr demonstrated excellent control on every evaluated dose. The mixture with 2, 4-D can reduce haloxyfop efficiency at low doses. Clethodim alone or mixed with 2,4-D or furoxypyr did not provide acceptable level of control.
\end{abstract}

Keywords: enetically modified, in tank mixture, ACCase inhibitors, auxin inhibitors, antagonism, and rampant weed.

RESUMO - Os grãos perdidos na colheita de culturas tolerantes ao glyphosate podem originar plantas voluntárias que apresentam restrições ao manejo de dessecação no sistema de plantio direto, bem como causar interferência na cultura sucessora transgênica ou convencional. Objetivou-se neste trabalho avaliar o controle do milho voluntário tolerante ao glyphosate em dois estádios de desenvolvimento. Dois experimentos foram conduzidos: um para o controle no estádio $V^{5}$ e outro para o controle no estádio $V^{8}$ do milho hibrido triplo $2 B 688 \mathrm{HR}$ (tolerante a lepidópteros e ao glyphosate). Utilizou-se o delineamento de blocos casualizados com quatro repetições. Os tratamentos avaliados foram: haloxyfop (25 $\left.\mathrm{g} \mathrm{ha}^{-1}\right)$, haloxyfop (50 $\left.\mathrm{g} \mathrm{ha}^{-1}\right)$, haloxyfop (62 $\mathrm{g} \mathrm{ha}$ ), haloxyfop + 2,4-D (25 + $\left.670 \mathrm{~g} \mathrm{ha}^{-1}\right)$, haloxyfop $+2,4-D\left(50+670 \mathrm{~g} \mathrm{ha}^{-1}\right)$, haloxyfop $+2,4-\mathrm{D}(62+670 \mathrm{~g} \mathrm{ha}$ ), haloxyfop + fluroxypyr $\left(25+200 \mathrm{~g} \mathrm{ha}^{-1}\right)$, haloxyfop + fluroxypyr $\left(50+200 \mathrm{~g} \mathrm{ha}^{-1}\right)$, haloxyfop + fluroxypyr $(62+$ $\left.200 \mathrm{~g} \mathrm{ha}^{-1}\right)$, clethodim $\left(84 \mathrm{~g} \mathrm{ha}^{-1}\right)$, clethodim $+2,4-\mathrm{D}\left(84+670 \mathrm{~g} \mathrm{ha}^{-1}\right)$, clethodim + fluroxypyr $\left(84+200 \mathrm{~g} \mathrm{ha}^{-1}\right)$ e uma testemunha sem aplicação. As aplicações no estádio $V^{5}$ do haloxyfop e do clethodim isolados ou em mistura com 2,4-D e com fluroxypyr apresentaram controle máximo (100\%) entre 32 e 39 dias após a aplicação, com exceção da mistura haloxyfop +2,4-D (25 + $670 \mathrm{~g} \mathrm{ha-1)}$ que não promoveu controle satisfatório. Para o estádio $V^{8}$, as misturas haloxyfop +2,4-D (50+670 $\mathrm{g}$ ha $\left.\mathrm{h}^{-1}\right)$ e haloxyfop $+2,4-D\left(62+670 \mathrm{~g} \mathrm{ha}^{-1}\right)$ demoraram até 6 e 10 dias a mais para atingirem controle satisfatório a excelente, quando comparados com as aplicações isoladas do haloxyfop nas mesmas

Recebido para publicação em 8.5.2014 e aprovado em 22.7.2014.

2 Universidade Estadual do Oeste do Paraná, Marechal Cândido Rondon-PR, Brasil, <neumarcio.costa@unioeste.br>; ${ }^{3}$ Crop Protection, R\&D, Dow AgroSciences Industrial Ltda, São Paulo-SP, Brasil; ${ }^{4}$ Universidade Católica do Paraná, Toledo-PR, Brasil.

Planta Daninha, Viçosa-MG, v. 32, n. 4, p. 675-682, 2014 
doses, respectivamente. O clethodim aplicado isolado e em mistura com 2,4-D e com fluroxypyr não apresentou controle satisfatório. Concluiu-se que os herbicidas mostraram controle eficiente em aplicações no estádio $V^{5}$ das plantas do milho voluntário transgênico, com exceção da mistura haloxyfop $+2,4-D\left(25+670 \mathrm{~g} \mathrm{ha}^{-1}\right)$. Para as aplicações no estádio $\mathrm{V}^{8}$, o haloxyfop isolado e em mistura com fluroxypyr foi o que demonstrou controle excelente em todas as doses avaliadas. A mistura com 2,4-D pode reduzir a eficiencia do haloxyfop em baixas doses. O clethodim isolado e em mistura com o 2,4-D ou com fluroxypyr não foi eficiente.

Palavras-chave: transgênico, mistura em tanque, inibidores da ACCase, inibidores de auxinas, antagonismo, planta daninha.

\section{INTRODUCTION}

The grain loss of hybrids tolerant to glyphosate in corn crops may hinder weed management, especially if the next crop is also genetically modified, due to the emergence of herbicide tolerant volunteer plants (Steckel et al., 2009). Unlike conventional maize hybrids, glyphosate does not control volunteer plants derived from tolerant hybrids efficiently (Deen et al., 2006).

Glyphosate tolerant volunteer corn plants can compete for production factors of with crops in succession, being classified as weed (Terry et al., 2012; Marquardt et al., 2012a, b). Thus, the degree of interference exerted by glyphosate tolerant corn volunteer plants can reach yield losses rates of $23 \%$ in corn, $18 \%$ in soybean, $19 \%$ in sugar beet and $8 \%$ in the production of cotton fibers (Thomas et al., 2007; Marquardt et al., 2012b; Kniss et al., 2012).

Therefore, the use of tank mixtures with ACCase inhibitors graminicides can be an excellent alternative in desiccation handling and post-emergence of transgenic soybean (Deen et al., 2006; Maciel et al., 2013).

The tank mixture with graminicides is also being used in areas where there is glyphosate tolerant weeds occurrence such as Lolium multiflorum and Digitaria insularis and management in desiccation for associations with glyphosate and auxinic ACCase inhibitors, may expand the spectrum action efficiency, particularly in areas where the infestation complex is still comprised by Conyza sp. tolerant biotypes, and other glyphosate-tolerant species, such as Commelina spp., Ipomoea sp., Euphorbia heterophylla, Spermacoce latifolia and Richardia brasiliensis (Maciel et al., 2013).
According Trezzi et al. (2007), antagonistic effect of 2,4-D may occur on the graminicides ACCase inhibitors action. Consequently, it becomes necessary to evaluate mixtures and formulations that reduce this effect.

The work hypothesis is based on the fact that volunteer corn plants derived from glyphosate-tolerant GM crops may become important competitors in succession crops, like soybeans. Thus, the use of haloxyfop and clethodim herbicides mixed with 2,4-D or fluroxypyr can be an excellent management option, in addition to presenting wide spectrum of weed control. However, graminicides efficiency may depend on the dose and formulations of auxinic used in tank mixture, as well as the developmental stage of transgenic volunteer corn plants at the time of application.

Thus, the present study aimed to evaluate the control of volunteer glyphosate tolerant corn at two stages of development with grass herbicides ACCase inhibitors and mixture with auxin mimics.

\section{MATERIAL AND METHODS}

The experiments were conducted in the field, in an area with the following coordinates: 2442'30 'S latitude, 54'longitude 21'10'W GRW and $485 \mathrm{~m}$ altitude. In Figure 1 the weekly temperature and precipitation for the period of experiments conduction are presented.

The soil was classified as eutroferric Red Latosol, in a clayey texture (Embrapa, 1999). The soil chemical analysis result presented the following characteristics: $\mathrm{pH}\left(\mathrm{CaCl}_{2}\right)=5.68$; organic matter $=19.2 \mathrm{~g} \mathrm{dm}^{-3}$; phosphorus $=26.44 \mathrm{mg} \mathrm{dm}^{-3} ; \mathrm{H}+\mathrm{Al}=3.03 \mathrm{cmol}_{\mathrm{c}} \mathrm{dm}^{-3}$; 


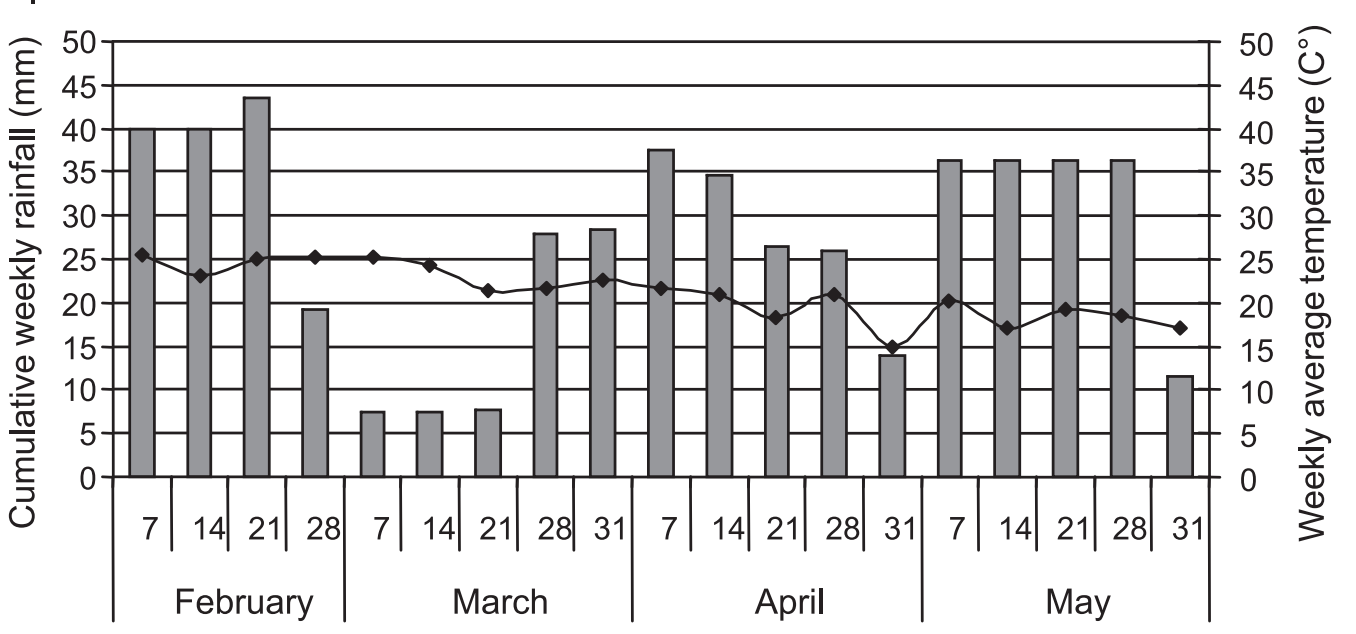

\section{Cumulative rainfall $(\mathrm{mm}) \rightarrow-$ Average temperature $\left(\mathrm{C}^{\circ}\right)$}

Figure 1 - Cumulative rainfall $(\mathrm{mm})$ weekly data and average temperature $\left({ }^{\circ} \mathrm{C}\right)$ during the collected experiments conduction by automatic weather station in Marechal Cândido Rondon.

$\mathrm{K}=0.73 \mathrm{cmol}_{\mathrm{c}} \mathrm{dm}^{-3} ; \mathrm{Ca}=5.41 \mathrm{cmol}_{\mathrm{c}} \mathrm{dm}^{-3}$ $\mathrm{Mg}=2.26 \mathrm{cmol}_{\mathrm{c}} \mathrm{dm}^{-3} ; \mathrm{SB}=8.4 \mathrm{cmol}_{\mathrm{c}} \mathrm{dm}^{-3}$ $\mathrm{CTC}=11.4 \mathrm{cmol}_{\mathrm{c}} \mathrm{dm}^{-3} ; \mathrm{e} \mathrm{V} \%=74$. The soil physical analysis results showed the following characteristics: clay $=631.0 \mathrm{~g} \mathrm{~kg}^{-1}$ of soil, sand $=110.7 \mathrm{~g} \mathrm{~kg}^{-1}$ of soil, and silt $=258.3 \mathrm{~g} \mathrm{~kg}^{-1}$ of soil.

The experimental design used in both experiments was a randomized complete block design (RBD) with four replications. The treatments applied in two phenological stages of volunteer corn are described in Table 1. An experiment using applications of herbicides to control volunteer corn at V5 and another one using applications at the V8 stage were performed, according to the phenological scale from Ritchie \& Hanway (1993).

We used the hybrid triple 2B688 RH maize (Lepidoptera and glyphosate tolerant). The plots consisted of four planting rows, spaced 0.7 meters between them and 7 meters long. Corn was sown in no-tillage on 20.02.2013, the density of four plants per linear meter, using a seeder consisted of six lines. After sowing, any cultural tract was conduct, just to assume the occurrence of volunteer plants.

Herbicide application at the first stage ( $\left.\mathrm{V}^{5}\right)$ was held on 28.03.2013, and on the second stage $\left(\mathrm{V}^{8}\right)$ on 09.04 .2013 , both in the morning.
A pressurized $\mathrm{CO}_{2}$ sprayer equipped with four XR 110015 tips $0.5 \mathrm{~m}$ spaced, with spray volume of $150 \mathrm{~L} \mathrm{ha}^{-1}$ was used. At the treatments application time at $\mathrm{V}^{5}$ stage,

Table 1 - Herbicides used for volunteer glyphosate tolerant corn control in the $\mathrm{V}^{5}$ and $\mathrm{V}^{8}$ growth stages. Entre Rios do Oeste, 2013

\begin{tabular}{|l|c|c|}
\hline \multicolumn{1}{|c|}{ Herbicide } & $\begin{array}{c}\text { Dosage } \\
\left(\mathrm{g} \mathrm{ha}^{-1}\right)\end{array}$ & $\begin{array}{c}\text { Mineral Oil } \\
\left(0.5 \% \mathrm{v} \mathrm{v}^{-1}\right)\end{array}$ \\
\hline Testemunha & --- & --- \\
\hline Haloxyfop & 25 & Joint Oil $^{\circledR}$ \\
\hline Haloxyfop & 50 & Joint Oil $^{\circledR}$ \\
\hline Haloxyfop & 62 & Joint Oil $^{\circledR}$ \\
\hline Haloxyfop + 2,4-D & $25+670$ & Joint Oil $^{\circledR}$ \\
\hline Haloxyfop + 2,4-D & $50+670$ & Joint Oil $^{\circledR}$ \\
\hline Haloxyfop + 2,4-D & $62+670$ & Joint Oil $^{\circledR}$ \\
\hline Haloxyfop+ fluroxypyr & $25+200$ & Joint Oil $^{\circledR}$ \\
\hline Haloxyfop+ fluroxypyr & $50+200$ & Joint Oil $^{\circledR}$ \\
\hline Haloxyfop+ fluroxypyr & $62+200$ & Joint Oil $^{\circledR}$ \\
\hline Clethodim & 84 & Lanzar $^{\circledR}$ \\
\hline Clethodim + 2,4-D & $84+670$ & Lanzar $^{\circledR}$ \\
\hline Clethodim + fluroxypyr & $84+200$ & Lanzar $^{\circledR}$ \\
\hline
\end{tabular}

Joint $\mathrm{Oil}^{\mathbb{E}}$ - (Mineral oil - mixture of paraffinic and cycloparaffinic hydrocarbons and saturated and unsaturated aromatic derived from petroleum distillation); Lanzar ${ }^{\circledR}$ - (phosphoric acid ethoxylated alkyl ester); haloxyfop (Verdict CE - $120 \mathrm{~g} \mathrm{~L}^{-1}$ ); 2,4-D, dimethylamine salt (DMA $806^{\circledR} \mathrm{SL},-670 \mathrm{~g} \mathrm{~L}^{-1}$ ); fluroxypyr (Starane CE - $200 \mathrm{~g} \mathrm{~L}^{-1}$ ), and clethodim (Select EC - $240 \mathrm{~g} \mathrm{~L}^{-1}$ ). 
temperature condition was $29.8{ }^{\circ} \mathrm{C}$, with relative humidity of $59 \%$ and winds of $4.8 \mathrm{~km} \mathrm{~h}^{-1}$; at the $\mathrm{V} 8$ the condition was $28.5^{\circ} \mathrm{C}$, with relative humidity of $64 \%$ and winds of $5.3 \mathrm{~km} \mathrm{~h}^{-1}$.

The effects of corn plants tolerant to glyphosate control at both levels were evaluated at $7,14,21,28,35$ and 42 days after application (DAA), through a range of visual score percentage, in which 0 (zero) corresponds to no injury demonstrated by the plant and 100 (one hundred) to the death of plants, according to the proposal of the Brazilian Society of Weed Science - SBCPD (1995).

At 42 DAA the dry matter was determined by collecting plants per linear meter from the two center rows of each plot, drying them in forced air circulation oven at $65^{\circ} \mathrm{C}$ for $72 \mathrm{~h}$; then they were weighed on a precision balance $(0.001 \mathrm{~g})$.

The control data were fitted to regression models based on assessment time, with equations being chosen based on significant models using biological logic and high $\mathrm{R}^{2}$. Through the first derivative of the regression equations, we determined the maximum control for both stages of application. The dry matter data were subjected to variance analysis and average Scoot-Knott 5\% probability test.

\section{RESULTS AND DISCUSSION}

Figure 2 shows the results of glyphosate tolerant corn control after herbicide application at $\mathrm{V}^{5}$ leaf stage, the results were obtained by regression. It was observed that the mixture of haloxyfop $\left(670+25 \mathrm{~g} \mathrm{ha}^{-1}\right)+$ $2,4-\mathrm{D}$ gave us poor control $(<80 \%)$ at the DAA. This result can probably be attributed to the occurrence of antagonism between both herbicides; however, as the dose of haloxyfop was increased, there was no reduction in the control of volunteer glyphosate tolerant corn efficiency.

This result corroborates those obtained by Maciel et al. (2013), who noted the antagonism in the mix of haloxyfop + 2,4-D (25 + $\left.670 \mathrm{~g} \mathrm{ha}^{-1}\right)$ at 7 and $14 \mathrm{DAA}$ for the $\mathrm{V}^{5}$ and $\mathrm{V}^{7}$ stages of hybrids tolerant to glyphosate DKB 240 PRO 2, RR2 AG 8025, AG 9045 RR2 and P 30F53 HR corn. However, from the $21^{\text {st }}$ DAA this mixture provided control above $87 \%$ for both

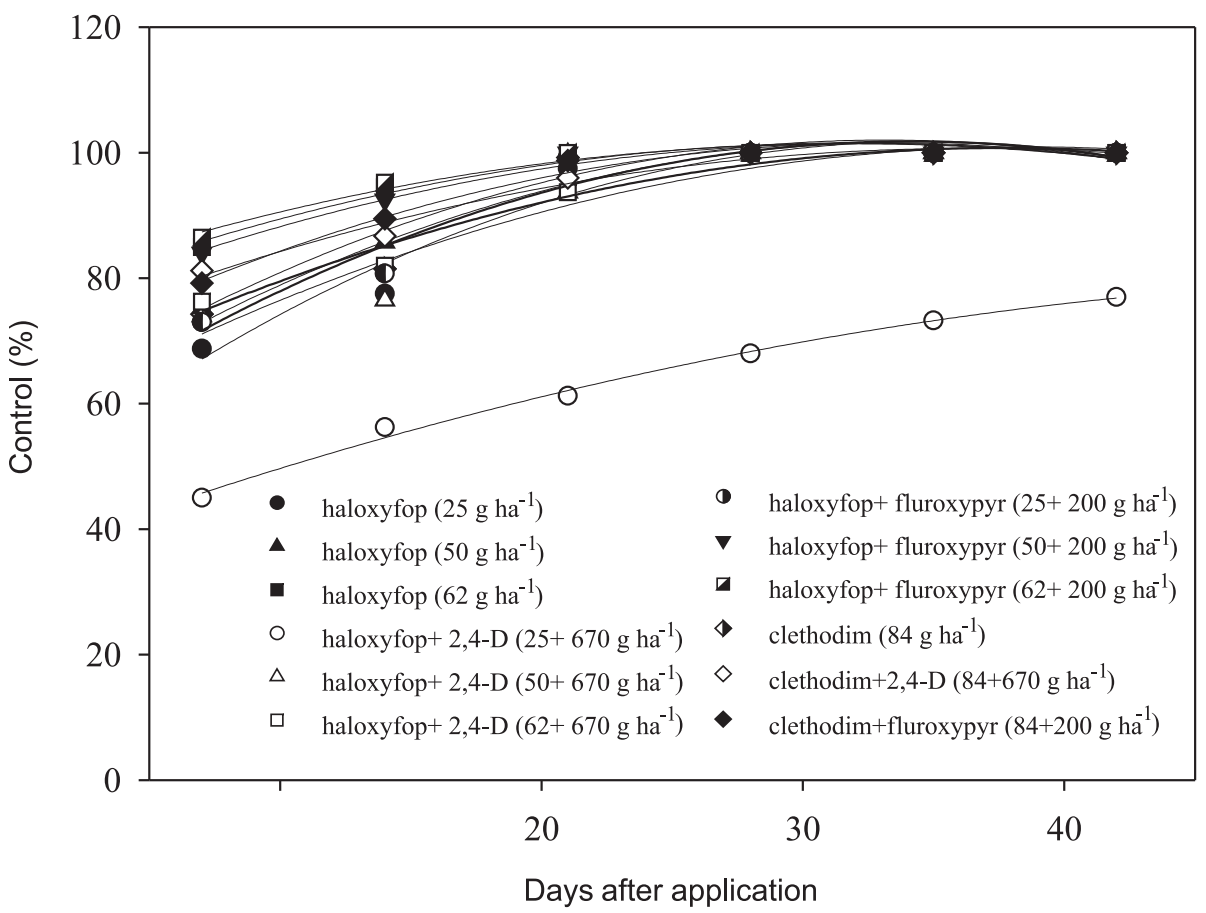

Figure 2 - Volunteer glyphosate tolerant corn (2B688 HR) control at growth stage $\mathrm{V}^{5}$ at 42 days after herbicide application. Entre Rios do Oeste-PR, 2013. 
growth evaluated stages. Those authors claim that it is necessary to increase haloxyfop concentration to improve control action speed when used in combination with 2,4-D. This result was also observed in the present work.

The other treatments showed excellent control (> 90\%) from 30 DAA. Table 2 shows the glyphosate tolerant (HR 2B688) corn data control regressions equations at growth stage $\mathrm{V}^{5}$, as shown in Figure 2.

Figure 3 shows volunteer glyphosate tolerant corn (2B688 HR) control results after herbicide application to the $\mathrm{V}^{8}$ growth stage. Table 3 gives the glyphosate tolerant volunteer corn data control regression equations in $\mathrm{V}^{8}$ growth stage.

Table 2 - Glyphosate tolerant volunteer corn (2B688 HR) data control regression equations at growth stageV5. Entre Rios do OestePR, 2013

\begin{tabular}{|l|c|c|c|}
\hline Treatment & $\begin{array}{c}\text { Dosage } \\
\left(\mathrm{g} \mathrm{ha}^{-1}\right)\end{array}$ & Equation & $\mathrm{R}^{2}$ \\
\hline Haloxyfop & 25 & $\hat{y}=47.37+3.13 \mathrm{x}-0.04 \mathrm{x}^{2}$ & $0.94 * *$ \\
\hline Haloxyfop & 50 & $\hat{y}=56.12+2.67 \mathrm{x}-0.03 \mathrm{x}^{2}$ & $0.93 * *$ \\
\hline Haloxyfop & 62 & $\hat{y}=75.85+1.61 \mathrm{x}-0.02 \mathrm{x}^{2}$ & $0.95 * *$ \\
\hline Haloxyfop + 2,4-D & $25+670$ & $\hat{y}=35.60+1.54 \mathrm{x}-0.01 \mathrm{x}^{2}$ & $0.99 * *$ \\
\hline Haloxyfop + 2,4-D & $50+670$ & $\hat{y}=56.45+2.29 \mathrm{x}-0.02 \mathrm{x}^{2}$ & $0.92^{* *}$ \\
\hline Haloxyfop + 2,4-D & $62+670$ & $\hat{y}=58.70+2.61 \mathrm{x}-0.03 \mathrm{x}^{2}$ & $0.96 * *$ \\
\hline Haloxyfop + fluroxypyr & $25+200$ & $\hat{y}=54.02+2.80 \mathrm{x}-0.04 \mathrm{x}^{2}$ & $0.93 * *$ \\
\hline Haloxyfop+ fluroxypyr & $50+200$ & $\hat{y}=73.75+1.71 \mathrm{x}-0.02 \mathrm{x}^{2}$ & $0.96 * *$ \\
\hline Haloxyfop+ fluroxypyr & $62+200$ & $\hat{y}=78.32+1.45 \mathrm{x}-0.02 \mathrm{x}^{2}$ & $0.95 * *$ \\
\hline Clethodim & 84 & $\hat{y}=56.12+2.67 \mathrm{x}-0.03 \mathrm{x}^{2}$ & $0.93 * *$ \\
\hline Clethodim + 2,4-D & $84+670$ & $\hat{y}=69.50+1.71 \mathrm{x}-0.02 \mathrm{x}^{2}$ & $0.97 * *$ \\
\hline Clethodim + fluroxypyr & $84+200$ & $\hat{y}=66.22+2.13 \mathrm{x}-0.03 \mathrm{x}^{2}$ & $0.97 * *$ \\
\hline
\end{tabular}

** significant at $1 \%$ by $\mathrm{F}$ test.

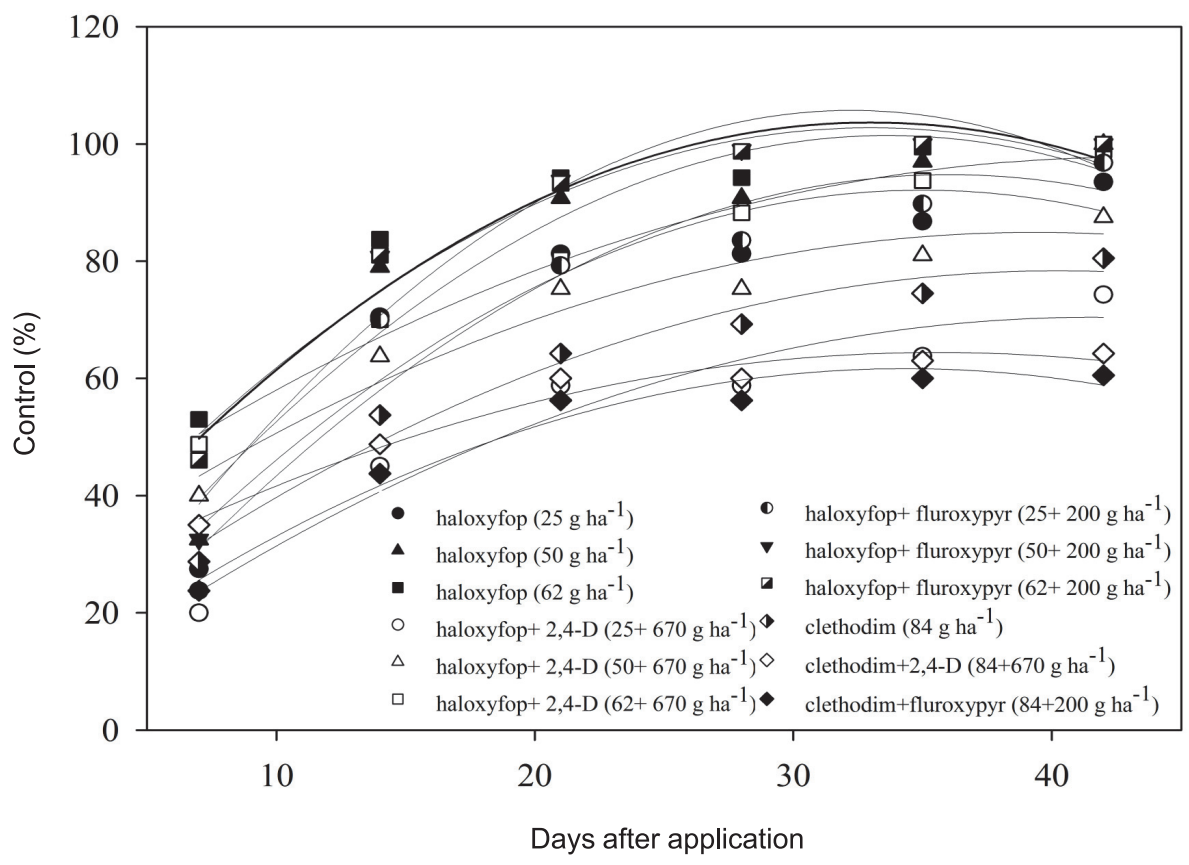

Figura 3 - Controle do milho voluntário tolerante ao glifosato (2B688 HR) no estádio fenológico V aos 42 dias após a aplicação dos herbicidas. Entre Rios do Oeste-PR, 2013. 
Table 3 - Control glyphosate tolerant volunteer corn (2B688 HR) adjusted data regression equations at growth stage $\mathrm{V}^{8}$. Entre Rios do Oeste-PR, 2013

\begin{tabular}{|l|c|c|c|}
\hline \multicolumn{1}{|c|}{ Treatment } & $\begin{array}{c}\text { Dosage } \\
\left(\mathrm{g} \mathrm{ha}^{-1}\right)\end{array}$ & Equation & $\mathrm{R}^{2}$ \\
\hline Haloxyfop & 25 & $\hat{y}=1.87+5.15 \mathrm{x}-0.07 \mathrm{x}^{2}$ & $0.89^{* *}$ \\
\hline Haloxyfop & 50 & $\hat{y}=2.60+5.87 \mathrm{x}-0.08 \mathrm{x}^{2}$ & $0.90^{* *}$ \\
\hline Haloxyfop & 62 & $\hat{y}=18.52+5.10 \mathrm{x}-0.07 \mathrm{x}^{2}$ & $0.91^{* *}$ \\
\hline Haloxyfop + 2,4-D & $25+670$ & $\hat{y}=2.75+3.25 \mathrm{x}-0.03 \mathrm{x}^{2}$ & $0.93^{* *}$ \\
\hline Haloxyfop + 2,4-D & $50+670$ & $\hat{y}=23.32+3.13 \mathrm{x}-0.03 \mathrm{x}^{2}$ & $0.94^{* *}$ \\
\hline Haloxyfop + 2,4-D & $62+670$ & $\hat{y}=30.45+3.11 \mathrm{x}-0.03 \mathrm{x}^{2}$ & $0.98^{* *}$ \\
\hline Haloxyfo + fluroxypyr & $25+200$ & $\hat{y}=-3.72+5.46 \mathrm{x}-0.07 \mathrm{x}^{2}$ & $0.91^{* *}$ \\
\hline Haloxyfo + fluroxypyr & $50+200$ & $\hat{y}=-3.92+6.79 \mathrm{x}-0.10 \mathrm{x}^{2}$ & $0.94^{* *}$ \\
\hline Haloxyfop + fluroxypyr & $62+200$ & $\hat{y}=9.62+5.78 \mathrm{x}-0.08 \mathrm{x}^{2}$ & $0.95^{* *}$ \\
\hline Clethodim & 84 & $\hat{y}=9.90+3.40 \mathrm{x}-0.04 \mathrm{x}^{2}$ & $0.97^{* *}$ \\
\hline Clethodim + 2,4-D & $84+670$ & $\hat{y}=20.35+2.47 \mathrm{x}-0.03 \mathrm{x}^{2}$ & $0.96^{* *}$ \\
\hline Clethodim + fluroxypyr & $84+200$ & $\hat{y}=4.75+3.31 \mathrm{x}-0.04 \mathrm{x}^{2}$ & $0.96^{* *}$ \\
\hline
\end{tabular}

** significant at $1 \%$ by $\mathrm{F}$ test.

Application of clethodim $\left(84 \mathrm{ha}^{-1}\right)$ alone and in combination with $2,4-\mathrm{D}\left(670 \mathrm{ha}^{-1}\right)$ and fluroxypyr $\left(200 \mathrm{~g} \mathrm{ha}^{-1}\right)$ resulted in unsatisfactory control $(<80 \%)$ compared to other treatments 42 DAA; this result may be related to the advanced development stage of transgenic volunteer corn plants.

Marquardt \& Johnson (2013) found in the transgenic soybean culture (P93M61) that clethodim + glyphosate $\left(79+840 \mathrm{~g} \mathrm{ha}^{-1}\right)$ mixture gave excellent control (>90\%) of $30 \mathrm{~cm}$ and $90 \mathrm{~cm}$ heigh transgenic volunteer corn plants (DKC 61-19) at 14 and 28 DAA, respectively. It is noteworthy that these authors have added $2 \% \mathrm{v} \mathrm{v}^{-1}$ of ammonium sulfate in the spray liquid, which explains the efficient control promoted by clethodim with less amount than the dose used in the present study. This may have maximized the absorption of herbicides by plants of volunteer corn (Blackshaw et al., 2006).

The haloxyfop alone and in combination with 2,4-D and fluroxypyr promoted satisfactory control of glyphosate tolerant volunteer corn at 42 DAA, with the exception of haloxyfop mixture + 2,4-D $\left(25+670 \mathrm{~g} \mathrm{ha}^{-1}\right)$, which showed unsatisfactory control. However, it was found that the control effect of the mixtures haloxyfop $+2,4-D$ was slower than the individual applications of haloxyfop or mixtures with fluroxypyr form, and less effective than the control applied at $\mathrm{V}^{5}$.

Trezzi et al. (2007) observed the antagonistic effect of mixing clonadifoppropargyl + 2,4-D (20 $\left.670 \mathrm{~g} \mathrm{ha}^{-1}\right)$ in control of ryegrass (Lolium mutiflorum) regarding the application of the graminicide isolated, as well as higher rates of control with the mixture as the clonadifop-propargyl concentration was increased. As to Velloso \& Dal'piaz (1982), they reported the existence of incompatibility mixture diclofop + dicamba + 2,4-D (720 + 576 $+97 \mathrm{~g} \mathrm{ha}^{-1}$ ) used in the control of ryegrass (Lolium mutiflorum) and Gorga (Spergula arvensis) on wheat, barley and rye.

In another study, Scherder et al. (2005) found that cyhalofop $\left(220 \mathrm{~g} \mathrm{ha}^{-1}\right)$ used in admixture or after triclopyr $\left(280 \mathrm{~g} \mathrm{ha}^{-1}\right)$ severely reduced biotypes control of propanil susceptible and tolerant Echinochloa crus-galli, compared with the separate application of the graminicide $\left(220 \mathrm{~g} \mathrm{ha}^{-1}\right)$.

Blackshaw et al. (2006) found antagonism in the mixture of clethodim-D amine +2.4 $\left(30+420 \mathrm{~g} \mathrm{ha}^{-1}\right)$ and quizalofop-P-D amine +2.4 $\left(36+420 \mathrm{~g} \mathrm{ha}^{-1}\right)$ through the lowest volunteer AC Barrie wheat biomass reduction, compared with graminicides individual applications, as well as the amine formulation provided the 
Table 4 - Days after the application for optimum control of glyphosate tolerant volunteer corn (2B688 RH). Entre Rios do OestePR, 2013

\begin{tabular}{|c|c|c|c|c|c|}
\hline \multirow[b]{2}{*}{ Treatment } & \multirow{2}{*}{$\begin{array}{l}\text { Dosage } \\
\left(\mathrm{g} \mathrm{ha}^{-1}\right)\end{array}$} & \multicolumn{2}{|c|}{$\mathrm{V}^{5}$} & \multicolumn{2}{|c|}{$\mathrm{V}^{8}$} \\
\hline & & DAA & $\begin{array}{l}\text { Maximum } \\
\text { control (\%) }\end{array}$ & DAA & $\begin{array}{l}\text { Maximum } \\
\text { control }(\%)\end{array}$ \\
\hline Haloxyfop & 25 & 34.7 & 100.0 & 34.9 & 92.1 \\
\hline Haloxyfop & 50 & 33.1 & 100.0 & 33.6 & 100.0 \\
\hline Haloxyfop & 62 & 31.9 & 100.0 & 32.9 & 100.0 \\
\hline Haloxyfop + 2,4-D & $25+670$ & 57.8 & 80.2 & 41.4 & 70.1 \\
\hline Haloxyfop + 2,4-D & $50+670$ & 38.7 & 100.0 & 39.3 & 84.9 \\
\hline Haloxyfop + 2,4-D & $62+670$ & 33.1 & 100.0 & 43.1 & 97.7 \\
\hline Haloxyfop + fluroxypyr & $25+200$ & 34.1 & 100.0 & 36.0 & 95.1 \\
\hline Haloxyfop + fluroxypyr & $50+200$ & 32.4 & 100.0 & 32.2 & 100.0 \\
\hline Haloxyfop + fluroxypyr & $62+200$ & 31.7 & 100.0 & 32.7 & 100.0 \\
\hline Clethodim & 84 & 34.1 & 100.0 & 40.2 & 78.3 \\
\hline Clethodim + 2,4-D & $84+670$ & 36.4 & 100.0 & 35.5 & 64.2 \\
\hline Clethodim + fluroxypyr & $84+200$ & 33.1 & 100.0 & 34.3 & 61.4 \\
\hline
\end{tabular}

highest antagonism to the formulation of $2,4-$ $\mathrm{D}$ on ester herbicide mixture.

Table 4 shows the volunteer glyphosate tolerant corn maximum control values as well as the period through which each developmental stage was reached $\left(\mathrm{V}^{5}\right.$ and $\left.\mathrm{V}^{8}\right)$, obtained by the first derivative of the regression equations in Tables 2 and 3.

It can be checked, for the $\mathrm{V}^{5}$, that haloxyfop and clethodim applied alone or in mixture with 2,4-D and fluroxypyr showed maximum control between 31.7 and 38.7 DAA, with the exception of haloxyfop mixture + 2 4-D $\left(670+25 \mathrm{~g} \mathrm{ha}^{-1}\right)$, that would take 57.8 DAA to promote satisfactory control $(80.2 \%)$.

Mixtures of haloxyfop + 2,4-D did not promote $100 \%$ control of volunteer corn plants tolerant to glyphosate at the $\mathrm{V}^{8}$ stage, while it took $2,4-\mathrm{D}+\left(50+670 \mathrm{ha}^{-1}\right)+$ haloxyfop and haloxyfop mixtures 2,4-D (62 + $\left.670 \mathrm{~g} \mathrm{ha}^{-1}\right) 5.7$ and 10.2 days to achieve satisfactory control over the excellent when compared with the isolated haloxyfop applications at the same doses, respectively. In addition to the isolated application of clethodim (84 $\left.\mathrm{g} \mathrm{ha}^{-1}\right) \mathrm{did}$ not provide satisfactory control, mixtures containing 2,4-D and fluroxypyr severely impaired the action of clethodim in more advanced stages of volunteer glyphosate tolerant corn plants.

All treatments significantly reduced volunteer glyphosate tolerant corn dry matter compared to control in both plant development stages, as the data presented in Table 5.

Overall, these results highlight the importance of completing the management in the transgenic volunteer corn plant development early stages, as well as the action

Table 5 - Glyphosate tolerant volunteer corn plants (2B688 HR) dry matter at 42 days after application for the $\mathrm{V}^{5}$ and $\mathrm{V}^{8}$ growth stages. Entre Rios do Oeste-PR, 2013

\begin{tabular}{|c|c|c|c|}
\hline \multirow{2}{*}{ Treatment } & \multirow{2}{*}{$\begin{array}{l}\text { Dosage } \\
\left(\mathrm{g} \mathrm{ha}^{-1}\right)\end{array}$} & \multicolumn{2}{|c|}{ Dry Matter $\left(\mathrm{t} \mathrm{ha}^{-1}\right)$} \\
\hline & & V5 & V8 \\
\hline Haloxyfop & 25 & $0.26 \mathrm{~b}$ & $0.98 \mathrm{~b}$ \\
\hline Haloxyfop & 50 & $0.25 \mathrm{~b}$ & $1.17 \mathrm{~b}$ \\
\hline Haloxyfop & 62 & $0.24 \mathrm{~b}$ & $1.07 \mathrm{~b}$ \\
\hline Haloxyfop + 2,4-D & $25+670$ & $0.36 \mathrm{~b}$ & $1.16 \mathrm{~b}$ \\
\hline Haloxyfop + 2,4-D & $50+670$ & $0.30 \mathrm{~b}$ & $1.30 \mathrm{~b}$ \\
\hline Haloxyfop + 2,4-D & $62+670$ & $0.31 \mathrm{~b}$ & $1.21 \mathrm{~b}$ \\
\hline Haloxyfop + fluroxypyr & $25+200$ & $0.43 \mathrm{~b}$ & $1.69 \mathrm{~b}$ \\
\hline Haloxyfop + fluroxypyr & $50+200$ & $0.21 \mathrm{~b}$ & $1.32 \mathrm{~b}$ \\
\hline Haloxyfop + fluroxypyr & $62+200$ & $0.34 \mathrm{~b}$ & $1.07 \mathrm{~b}$ \\
\hline Clethodim & 84 & $0.21 \mathrm{~b}$ & $1.57 \mathrm{~b}$ \\
\hline Clethodim + 2,4-D & $84+670$ & $0.57 \mathrm{~b}$ & $1.88 \mathrm{~b}$ \\
\hline Clethodim + fluroxypyr & $84+200$ & $0.24 \mathrm{~b}$ & $1.59 \mathrm{~b}$ \\
\hline Testemunha & 0,00 & $10.00 \mathrm{a}$ & $17.26 \mathrm{a}$ \\
\hline $\mathrm{F}_{\text {Treatments }}$ & & $73.86^{* *}$ & $35.94 * *$ \\
\hline$F_{\text {Block }}$ & & $0.41 * *$ & $0.59 * *$ \\
\hline $\mathrm{CV}(\%)$ & & 59.25 & 57.53 \\
\hline
\end{tabular}

Average rates followed by the same letter in the column do not differ statistically by Scoot-Knott test at $5 \%$ probability. ** significant at $1 \%$ by $\mathrm{F}$ test.

Planta Daninha, Viçosa-MG, v. 32, n. 4, p. 675-682, 2014 
spectrum expanding possibility for weed control due to the use of herbicides in tank mixture with distinct action mechanisms. However, in haloxyfop and the 2,4-D mixture formulations antagonism can occur, and, thus, volunteer glyphosate-tolerant corn control efficacy reduction, particularly in advanced stages of the plant.

Therefore, it can be concluded that the application of haloxyfop and clethodim isolated or in mixture with 2,4-D and fluroxypyr at $\mathrm{V}^{5}$ growth stage of the glyphosate-tolerant volunteer corn plants gave excellent control (>90\%), except $2,4-\mathrm{D}+\left(25+670 \mathrm{~g} \mathrm{ha}^{-1}\right)$ haloxyfop mixture. As for the applications at $\mathrm{V}^{8}$ growth stage, haloxyfop alone and in combination with fluroxypyr was the one that showed excellent control in all evaluated doses. The 2,4-D mixture may reduce low-doses haloxyfop efficiency. The clethodim alone and in combination with 2,4-D or fluroxypyr was not effective.

\section{LITERATURE CITED}

LACKSHAW, R. E. et al. Broadleaf herbicide effects on clethodim and quizalofop-P efficacy on volunteer wheat (Triticum aestivu). Weed Tecnol., v. 20, n. 1, p. 221-226. 2006.

DEEN, W. et al. Control of Volunteer Glyphosate - Resistant Corn (Zea mays) in Glyphosate - Resistant Soybean (Glycine max). Weed Technol., v. 20, n. 1, p. 261-266, 2006.

EMPRESA BRASILEIRA DE PESQUISA AGROPECUÁRIA - EMBRAPA. Serviço Nacional de Levantamento e Conservação de Solos. Sistema Brasileiro de Classificação de Solos. Rio de Janeiro: 1999. $412 \mathrm{p}$.

KNISS, A. R.; SBATELLA, G. M.; WILSON, R. G. Volunteer Glyphosate-Resistant Corn Interference and Control in Glifosato-Resistant Sugarbeet. Weed Technol., v. 26, n. 2, p. 348-355. 2012.

MARQUARDT, P. T. et al. Competitive Effects of Volunteer Corn on Hybrid Corn Growth and Yield. Weed Sci., v. 60, n. 4, p. 37-541, 2012a.
MARQUARDT, P.; KRUPKE, C.; JOHNSON, W. G. Competition of Transgenic Volunteer Corn with Soybean and the Effect on Western Corn Rootworm Emergence.

Weed Sci., v. 60, n. 2, p. 193-198. 2012 b.

MACIEL, C. D. G. et al. Eficácia do herbicida haloxyfop R (GR-142) isolado e associado ao 2,4- D no controle de híbridos de milho RR ${ }^{\circledR}$ voluntário. R. Bras. Herbic., v. 12, n. 2, p. 112-123, 2013.

MARQUARDT, P. T.; JOHNSON, W. G. Influence of clethodim application timing on control of volunteer corn in soybean. Weed Technol., v. 27, n. 4, p. 645-648, 2013.

RITCHIE, S.; HANWAY, J. J. How a corn plant develops. Ames: Iowa State University of Science and Technology, Cooperative Extension Service, 1993. 21 p.

(Special Report, 48).

SOCIEDADE BRASILEIRA DA CIÊNCIA DAS PLANTAS DANINHAS - SBCPD. Procedimentos para instalação, avaliação e análise de experimentos com herbicidas.

Londrina: $1995.42 \mathrm{p}$.

SHERDER, E. F.; TALBERT, R. E.; LOVELACE, M. L. Antagonism of cyhalofop grass activity by halosulfuron, triclopyr, and propanil. Weed Technol., v. 19, n. 4, p. 934-941, 2005.

STECKEL, L. E.; THOMPSON, M. A.; HAYES, R. M. Herbicide options for controlling glyphosate-tolerant corn in a corn replant situation. Weed Technol., v. 23, n. 2, p. 243-246, 2009.

TERRY, R. M. et al. The Influence of Nitrogen Application Timing and Rate on Volunteer Corn Interference in Hybrid Corn. Weed Sci., v. 60, n. 3, p. 510-515, 2012.

THOMAS, W. E. et al. Glyphosate-Resistant Corn Interference in Glyphosate-Resistant Cotton.

Weed Technol., v. 21, n. 2 p. 372-377, 2007.

TREZZI, M. M. et al. Antagonismo das associações de clonadinafop- propargyl com metsulfuron- methyl e 2,4-D no controle de azevém (Lolium multiflorum). Planta Daninha, v. 25, n. 4, p. 839-847, 2007.

VELLOSO, J. A. R.; DAL'PIAZ, R. Controle de azevém (Lolium multiflorum L.), e gorga (Spergula arvensis L.) e seletividade de herbicidas as culturas de trigo, cevada e centeio. Planta Daninha, v. 2, n. 1, p. 8-13, 1982. 